\title{
Factors Affecting Capital Structure of Listed Construction Companies on Hanoi Stock Exchange
}

\author{
Nguyet Minh NGUYEN ${ }^{1}$, Kien Trung TRAN ${ }^{2}$
}

Received: August 01, 2020 Revised: September 30, 2020 Accepted: October 15, 2020

\begin{abstract}
The aim of this article is to determine the influence of factors on the capital structure of construction companies listed on the Hanoi Stock Exchange. The data of the article were collected and calculated from the financial statements of 54 construction companies listed on Hanoi Stock Exchange from 2012 to 2019. With the application of E-view software in quantitative analysis to build panel data regression model (panel data), the article has built a regression model to determine the relationship of intrinsic factors affecting the capital structure of construction companies listed on Hanoi Stock Exchange. In the study, dependent variable is capital structure, determined by the debt-toequity ratio. Profitability, coefficient of solvency, size, loan interest rate, structure of tangible assets, and growth are independent variables. The results showed that the two factors of growth and firm size positively affect the capital structure, the profitability factor has the opposite effect on capital structure. Factors of short-term debt solvency, average loan interest rate and tangible asset structure have no correlation with capital structure. The findings of this article are useful for business administrators, helping business managers make the right financial decisions to make capital structure decisions in their own conditions.
\end{abstract}

Keywords: Capital Structure, Construction Companies, Growth Rate, Profitability, Firm Size

JEL Classification Code: C01, G30, G32, L74

\section{Introduction}

Over the past years, along with the efforts to stabilize the macro-economy, the Government has made great attempts in improving the business environment. These efforts have contributed to the recovery of the economy. Although there have been many positive changes in the economy, the operation of businesses still faces difficulties. The impact from the economic crisis and recession is still a threat to the viability of the majority of businesses including construction businesses. In recent years, it can be seen that the performance of enterprises in the construction industry

${ }^{1}$ First Author and Corresponding Author. Lecturer, Faculty of Transport Economics, University of Transport Technology, Vietnam [Postal Address: 54 Trieu Khuc Road, Thanh Xuan District, Hanoi, 120418, Vietnam] Email: nguyetnm@utt.edu.vn

${ }^{2}$ Lecturer, Faculty of Transport Economics, University of Transport Technology, Vietnam. Email: kientt@utt.edu.vn

(C) Copyright: The Author(s)

This is an Open Access article distributed under the terms of the Creative Commons Attribution Non-Commercial License (https://creativecommons.org/licenses/by-nc/4.0/) which permits unrestricted non-commercial use, distribution, and reproduction in any medium, provided the original work is properly cited. has not been good, there have been many shortcomings in financial management. One of the primary causes leading to the above situation is the existence of an unreasonable, unsafe and risky capital structure mainly arising from the needs of enterprises.

Capital structure are related to corporate financing decisions. Firms can finance their operations using debts, equity or a combination of these two sources (Ross et al., 2001; Abor, 2005; Brealey et al., 2009).

Capital structure of construction enterprises often has a high debt ratio, a common situation in many countries around the world (Mohammad et al., 2019). In Vietnam, the capital structure of construction enterprises has a higher debt ratio, averaging $70 \%-80 \%$ of the total capital, even some enterprises have a debt ratio of over $90 \%$. While enterprises are operating inefficiently, the capital structure that leans too much on such debts puts more pressure on enterprises, both creating more difficulties for enterprises and containing potential risks. Using too much debt financing can increase financial exhaustion and reduce the firm's ability of to borrow (Addae et al., 2013). Therefore, in order to develop stably and sustainably, construction enterprises need to set up a reasonable capital structure to promote the efficiency 
of capital structure, helping businesses maximize corporate value, this is called the optimal capital structure (Nirajini \& Priya, 2013). Companies operating in the same industry have an equal level of operational risk and, therefore, have similar optimal capital structures (Morri \& Cristanziani, 2009). Therefore, from a financial perspective, the article will contribute to the knowledge of capital structures of construction companies listed on the Hanoi Stock Exchange by conducting empirical analysis to test and evaluate the influence of factors on the capital structure of construction enterprises listed on the Hanoi Stock Exchange to provide additional information as a basis for making funding decisions oriented towards the optimal capital structure of these businesses.

The other parts of this article are structured as follows: Part 2 provides a literature review of related studies, and then Part 3 describes the research methodology. Part 4 presents the research results and the author's discussion and analysis. Finally, conclusions and recommendations of the study are provided in Part 5.

\section{Literature Review and Hypotheses}

\subsection{Literature Review}

DeAngelo and Masulis (1980) predicted that the firm's debt ratio is inversely related to the level of the non-debt tax shields and his model focuses, not only on the non-debt tax shields, but also on predictions about leverage and profitability. Research by Harris (1988) proposed a model to study the relationship between asset structure and level of revenue on capital structure. By examining the hypothesis of the relationship between the level of financial leverage and the dividend payout ratio of US venture companies in the oil and gas industry, Gentry (1994) discovered that joint ventures are not subject to corporate income tax therefore they have higher dividend payout ratios and use less debt than their competitors. This is consistent with Modigliani and Miller Theory (M\&M) (1958) and studies of the impact of tax factors on capital structure choice.

In addition, Gropp (1995) conducted a study on the impact of taxes on the capital structure of enterprises and to produce a research model combining many business taxes of local governments affecting the capital structure of German businesses. The model also showed that the tax savings under the German Tax Law when businesses finance a certain proportion of their debt will vary according to local tax. Fischer et al. (1989) sought to find a relationship between transaction costs and the capital structure of firms according to the pecking order theory. He used the price option model and found out that only a small change in transaction costs could lead to a significant change in the target capital structure.
Similarly, research by Michaely et al. (1995) stated that, in contrast to the optimal theory of dividend payments, business managers seem to pay dividends on an incomebased basis in the past, rather than future earnings. In 2002, Baker and Wurgler conducted a survey of the effects of past earnings-to-equity ratios on the firm's capital structure, pointing out that this ratio of earnings is decisive factor affecting the issue of company shares (i.e., the decision to increase owner's equity of the business). Rajan and Zingales (1995) presented a very typical study on the capital structure of firms in OCED countries and found that there is a fairly closely opposite relationship between book value of stocks and financial leverage. Barclay et al. (1995) also found that the market price and book value of the firm is inversely related to the debt ratio.

Based on capital structure theories, many empirical studies in countries around the world have been carried out to find out the important factors affecting the capital structure of enterprises. Summarizing the research results, we can see the main factors affecting the capital structure of enterprises including: firm size, profitability, asset structure, growth ability, liquidity, business risks, and corporate income tax (Ross, 1977; Titman \& Wessels, 1988; Wald,1999). Mukhibad et al. (2020) studied about Determinants of Debt Policy for Public Companies in Indonesia. The results of the study found that companies' debt policies in Indonesia are negatively affected by the liquidity. Investment opportunity set (IOS) has negative effect on debt policy. Meanwhile, ROA, Return on Invested Capital (ROIC), and firm size of a company has no impact on debt policy.

In Vietnam, there have been many studies on capital structure, but none of these studies have focused on the factors affecting the capital structure of construction enterprises listed on the Hanoi Stock Exchange. Therefore, this article aims at identifying factors affecting capital structure to provide construction enterprises in general and construction enterprises listed on the Hanoi Stock Exchange in particular with more backgrounds to plan the target capital structure.

\subsection{Hypotheses}

Based on the theoretical and empirical research on financial risk, the authors set up six research hypotheses on the factors affecting capital structure of listed construction companies on Hanoi Stock Exchange is as follows:

Profitability: Some studies have shown that an inverse relationship exists between profitability and capital structure. They argue that a profitable enterprise tends to mobilize internal rather than external resources, and firms often reduce debt. This negative relationship can be found in the study of Baral (2004), Akhtar (2005), Gurcharan (2010), 
Shubiri (2010), Akinlo (2011), Sharif et al. (2012), Nguyen and Nguyen (2020). The hypothesis is as follows:

$\boldsymbol{H}_{l}$ : Profitability of listed construction companies is negatively correlated with capital structure.

Solvency: Many studies often suggest that an inverse relationship exists between solvency and capital structure because the more short-term assets an enterprise uses, the more internal cash flows it can generate to finance businesses and investments. Businesses with high solvency tend to use less debt. This view is supported by Eriotis (2007), Liu et al. (2009), Sharif et al. (2012). From the above arguments, the hypothesis of the correlation between the solvency and capital structure is:

$\boldsymbol{H}_{2}$ : The solvency of listed enterprises in construction is negatively correlated with capital structure.

Business size: Previous studies have shown that large firms often have a large proportion of debt in capital structure. Studies supporting this view include: Baral (2004), Akhtar (2005), Eriotis (2007), Liu et al. (2009), Gurcharan (2010). The hypothesis is as follows:

$\boldsymbol{H}_{3}$ : Business size of listed enterprises is positively correlated with capital structure.

Average loan interest rate: Although the loan interest rate is determined by the market, the average loan interest rate of the enterprise can be calculated on the firm's total debt, including corporate debt. Therefore, the average loan interest rate can be considered as an internal factor of the business. According to research by Huynh (2020), interest rates have a positive impact on capital structure. This can be explained: for businesses when operating, interest costs generated from borrowing and borrowing interest, are financial costs, so businesses will save tax when using loans. Therefore, when interest rates increase, businesses tend to use debt to save taxes. The hypothesis is as follows:

$\boldsymbol{H}_{4}$ : The average loan interest rate of construction listed firms is positively correlated with capital structure.

Asset structure: There are two contradictory views on the relationship between asset structure and firm's capital structure. The first point of view is that firms with large tangible assets can access loans more easily than firms with high intangible assets without collateral because of their own assets. Figure can be mortgaged to secure the loan. Studies supporting this view include Akhtar (2005), Shah and Khan (2007), Teker et al. (2009), Liu et al. (2009) and Shubiri (2010), Khan et al. (2020). The second viewpoint exists that an inverse relationship exists between asset structure and capital structure. Because they think that bond markets in small and developing countries make businesses depend on loans from banks. Moreover, banks often prefer short-term loans over long-term loans with many risks, which causes businesses to mobilize long-term loans instead of shortterm loans. This view is supported by Akinlo (2011). The hypothesis is as follows:

$\boldsymbol{H}_{5}$ : Asset structure of construction listed firms is positively correlated with capital structure.

Growth rate: There are two views on the relationship between growth rate and capital structure in the firm. The first is that firms with strong growth opportunities in the future are expected to raise more equity capital, suggesting an inverse relationship between growth likelihood and capital structure. This view is supported by Eriotis (2007), Liu et al. (2009), Gurcharan (2010), Akinlo (2011). The second view believes that this relationship is positive. Relying on the rationale that a high growth rate implies a large demand for capital, a greater reliance on external capital through debt, backed by Baral (2004), Shubiri (2010). The hypothesis is as follows:

$\boldsymbol{H}_{6}:$ Growth rate of listed enterprises in construction is positively correlated with capital structure.

\section{Research Methods}

\subsection{Research Data}

The research sample includes 8-year data (from 2012 to 2019) of 54 enterprises construction companies listed on Hanoi Stock Exchange. The source of data collected comes from information on stock exchanges and securities companies. These are reliable sources of information according to the author. The data used in the study was collected and analyzed from financial statements and financial information of construction enterprises listed on Hanoi Stock Exchange. The financial statements of these businesses are prepared on the basis of compliance with the Vietnamese accounting standards system and have been audited.

\subsection{Research Model}

According to AC Harvy's standards, the selection of an econometric model is based on certain criteria. The saving criterion is the first and foremost, which means that a simple model that can explain the fluctuation of the dependent variable by the explanatory variable can be seen as a good model. Based on that principle, econometric model was 
selected to test the impact of internal factors on capital structure of construction enterprises listed on Hanoi Stock Exchange, including:

Overall regression model:

$$
Y=\beta_{1}+\beta_{t} X_{t}+u_{i}
$$

In which:

Y : Dependent variable

$X_{\mathrm{n}} \quad$ : The independent variable affects the dependent variable

$\beta_{1} \quad$ : Free coefficient

$\beta_{\mathrm{t}} \quad:$ Regression coefficient $(t=2 \div n)$

$u_{\mathrm{i}} \quad$ : Random error

The theories of capital structure has shown that there are many factors (external factors and internal factors) affecting the capital structure of enterprises. However, in this study, due to the particular characteristics of Vietnam's economy, the stock market and listed companies, the author only tested some internal factors that affect the capital structure of enterprises.

In the specific regression model of the study, the firm's capital structure is represented by the ratio of debt to equity. Factors affecting the capital structure (CS) are selected on the basis of the characteristics of construction enterprises listed on Hanoi Stock Exchange, including: (1) Profitability of the business (BEP), (2) Solvency of short-term debt (SOL), (3) Firm size (SIZE), (4) Average loan interest rate of enterprises (INT), (5) Long-term asset ratio (LAR), (6) Growth rate (GRO). Although the interest rate variable is exogenous, each firm has different borrowing costs, so it is also possible to consider the loan interest rate as an internal variable of the business.

The model to study the factors affecting the capital structure of construction companies is described as follows (Figure 1).

Building and testing models:

The regression model parameters were estimated by E-view software.

Overall regression model:

$$
\begin{aligned}
C S_{i}= & \beta_{1}+\beta_{2} B E P_{i}+\beta_{3} S O L_{i}+\beta_{4} S I Z E_{i}+\beta_{5} I N T_{i} \\
& +\beta_{6} L A R_{i}+\beta_{7} G R O_{i}+u_{i}
\end{aligned}
$$

Overall regression function:

$$
\begin{aligned}
C S_{i}= & \beta_{1}+\beta_{2} B E P_{i}+\beta_{3} S O L_{i}+\beta_{4} S I Z E_{i}+\beta_{5} I N T_{i} \\
& +\beta_{6} L A R_{i}+\beta_{7} G R O_{i}
\end{aligned}
$$

In which:

Dependent variable CS: Capital structure of the business. It is determined by the debt to equity ratio of each of the 54 construction enterprises listed on the Hanoi Stock Exchange in the period of $2012-2019$.

The group of independent variables reflecting the factors that statistics are taken from the financial statements of 54 construction enterprises listed on the Hanoi Stock Exchange from 2012 - 2019 include:

- $\mathrm{BEP}_{\mathrm{i}}$ : The profitability variable of firm $\mathrm{i}$, which is measured by the rate of return on assets or profit before interest and tax on business capital of enterprise $\mathrm{i}$.

- $\mathrm{SOL}_{\mathrm{i}}$ : The variable coefficient of solvency of shortterm debt of enterprise $i$, which is determined by the ratio of short-term assets to short-term debts of the enterprise i.

- SIZE $_{\mathrm{i}}$ : The size variable of enterprise $i$, measured by the logarithm of the asset value of the enterprise $i$.

- INT: The average loan interest rate of enterprise $i$, which is determined by the interest expense on the average debt of the enterprise (including borrowed capital and appropriated capital, because appropriated capital may be considered as a loan with an interest rate of 0 ).

- LAR $\mathrm{R}_{\mathrm{i}}$ Variable structure of tangible assets of the enterprise, equal to the ratio of average long-term assets to total assets of the enterprise i.

- $\mathrm{GRO}_{\mathrm{i}}$ : Variable growth rate of an enterprise is equal to the growth rate of total assets of the enterprise $i$.

- $\beta_{\mathrm{i}}$ : The partial regression coefficient measures the change in the mean value of dependent variable CS when the independent variable changes one unit and the other independent variables remain unchanged.

- $\mathrm{u}_{\mathrm{i}}$ : Random error of the model.

The statistics are presented in the table below:

Profitability

Independent variables

Solvency of short-term debt

Business size

Average loan interest rate

The ratio of long-term assets

Growth rate

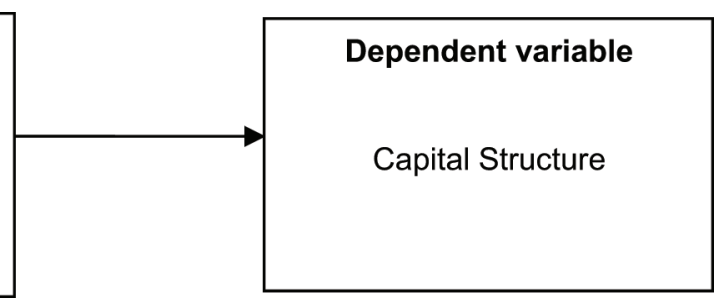

Figure 1: Research model of factors affecting the capital structure of enterprises 
The data in Table 1 show that the average debt-to-equity ratio of enterprises in the period 2012-2019 was 2,629145, but there was a large difference between enterprises, ranging from 0.011741 to 13.43602 . This is considered a characteristic of enterprises in the construction industry in Vietnam, there are many enterprises with very large debt ratio. Table 1 also shows the average value of profitability (BEP) of $4.7569 \%$, the average value of the short-term solvency ratio (SOL) is 2.130341 . The size of the business is measured by the logarithm of the average enterprise asset value (SIZE) of 8,590913 , the average interest rate of debt (INT) is $3.1177 \%$, the ratio of long-term assets to the average total assets. Average is 0.270372 and the average growth rate of total assets (GRO) is $7.3850 \%$.

\subsection{Research Method}

The study uses table data regression with three methods: Pooled Ordinary Least Squares (POLS), Random Effects Model (REM) and Fixed Effects Model (FEM). Including:

POLS method: A regression method that combines all observations, ignoring the time factor and the difference between cross units of table data. With this limitation, the POLS estimate can lead to a misleading estimate because in fact each firm has its own characteristics and it is possible that these characteristics affect the explanatory variables in the model. .

FEM method: It is assumed that each firm has its own characteristics and can affect independent variables in the model. Thereby, FEM analyzes this correlation between the error of each unit and the explanatory variables, thereby controlling and separating the effects of the individual characteristics (constant over time) from the explanatory variables to have It is possible to estimate the real effects of the explanatory variable on the dependent variable. However, FEM is limited when firms have volatility that is correlated with independent variables in the model.
REM method: In the case of fluctuations between cross units and the impact is correlated with the independent variables of the model, the REM model is used. In the REM model, the variation between the cross units is assumed to be random and not correlated with the explanatory variables.

\section{Research Results}

Run the model using E-view software and use the least squares method (OLS) to determine the regression coefficient $\beta \mathrm{i}$. Based on the results obtained when running the model, an equation of the factors affecting the capital structure will be written. Then, check the model's suitability, that is, test $\beta \mathrm{i}$ to find out whether the independent variable can explain the dependent variable or not. Assess the model's suitability using Adjusted R Square to determine the model's interpretability in practice.

Running the model using E-view software under Panel data, we have:

- Regression with the Random Effect method:

- Use Hausman Test to select a model:

The Hausman test is used to choose between two Random Effect Model and Fixed Effect Model. In essence, this is a test of whether unique errors correlate with the explanatory variables.

Test of hypothetical pairs:

$\int \mathrm{H}_{0}$ : There is no correlation between explanatory variables and random components (choose Random Effect)

$\mathrm{H}_{1}$ : There is a correlation between explanatory variables and random components (choose Fixed Effect)

Prob. $=0.0028<0.05$ should reject $\mathrm{H}_{0}$, select Fixed Effect model. Therefore, this article will use the Fixed Effect Model to regression to find out key factors affecting the financial structure of construction firms listed on the Hanoi Stock Exchange in the period of 2012- 2019.

Table 1: Descriptive Statistics

\begin{tabular}{|l|c|c|c|c|c|c|c|}
\hline & CS & BEP & SOL & SIZE & INT & LAG & GRO \\
\hline Mean & 2.629145 & 0.047569 & 2.130341 & 8.590913 & 0.031177 & 0.270372 & 0.073850 \\
\hline Median & 2.210523 & 0.040885 & 1.272875 & 8.597733 & 0.024321 & 0.188664 & 0.022821 \\
\hline Maximum & 13.43602 & 0.481960 & 105.7035 & 10.45358 & 1.470201 & 0.961068 & 4.599925 \\
\hline Minimum & 0.011741 & -0.576578 & 0.193205 & 7.373535 & 0.000000 & -0.119042 & -0.745190 \\
\hline Std. Dev. & 2.167749 & 0.076491 & 6.632503 & 0.598322 & 0.072783 & 0.210868 & 0.353349 \\
\hline Observations & 432 & 432 & 432 & 432 & 432 & 432 & 432 \\
\hline
\end{tabular}


Table 2: Regression results with Fixed Effect Model

\begin{tabular}{|c|c|c|c|c|}
\hline \multicolumn{5}{|c|}{ Dependent Variable: CS } \\
\hline \multicolumn{5}{|c|}{ Method: Panel Least Squares } \\
\hline \multicolumn{5}{|c|}{ Date: $08 / 12 / 20$ Time: $10: 16$} \\
\hline \multicolumn{5}{|c|}{ Sample: 20122019} \\
\hline \multicolumn{5}{|c|}{ Periods included: 8} \\
\hline \multicolumn{5}{|c|}{ Cross-sections included: 54} \\
\hline \multicolumn{5}{|c|}{ Total panel (balanced) observations: 432} \\
\hline Variable & Coefficient & Std. Error & t-Statistic & Prob. \\
\hline C & -17.52567 & 4.713028 & -3.718558 & 0.0002 \\
\hline BEP & -3.656765 & 0.970104 & -3.769458 & 0.0002 \\
\hline SOL & -0.014037 & 0.012291 & -1.142056 & 0.2542 \\
\hline SIZE & 2.385912 & 0.548669 & 4.348547 & 0.0000 \\
\hline INT & 0.587310 & 0.998383 & 0.588261 & 0.5567 \\
\hline LAR & -0.714408 & 0.604877 & -1.181081 & 0.2383 \\
\hline GRO & 0.492173 & 0.201955 & 2.437048 & 0.0153 \\
\hline \multicolumn{5}{|c|}{ Effects Specification } \\
\hline \multicolumn{5}{|c|}{ Cross-section fixed (dummy variables) } \\
\hline R-squared & 0.711198 & \multicolumn{2}{|c|}{ Mean dependent var } & 2.629145 \\
\hline F-statistic & 15.52674 & \multicolumn{2}{|c|}{ Durbin-Watson stat } & 0.750832 \\
\hline Prob (F-statistic) & 0.000000 & & & \\
\hline
\end{tabular}

Table 3: Regression results with Random Effect Model

\begin{tabular}{|c|c|c|c|c|}
\hline \multicolumn{5}{|c|}{ Dependent Variable: CS } \\
\hline \multicolumn{5}{|c|}{ Method: Panel EGLS (Cross-section random effects) } \\
\hline \multicolumn{5}{|c|}{ Date: $08 / 12 / 20$ Time: $10: 22$} \\
\hline \multicolumn{5}{|c|}{ Sample: 20122019} \\
\hline \multicolumn{5}{|l|}{ Periods included: 8} \\
\hline \multicolumn{5}{|c|}{ Cross-sections included: 54} \\
\hline \multicolumn{5}{|c|}{ Total panel (balanced) observations: 432} \\
\hline \multicolumn{5}{|c|}{ Swamy and Arora estimator of component variances } \\
\hline Variable & Coefficient & Std. Error & t-Statistic & Prob. \\
\hline $\mathrm{C}$ & -12.45773 & 2.162362 & -5.761164 & 0.0000 \\
\hline BEP & -3.773903 & 0.942316 & -4.004925 & 0.0001 \\
\hline SOL & -0.021734 & 0.011496 & -1.890562 & 0.0594 \\
\hline SIZE & 1.841676 & 0.251800 & 7.314055 & 0.0000 \\
\hline INT & 0.928533 & 0.968131 & 0.959098 & 0.3381 \\
\hline LAR & -2.157300 & 0.502581 & -4.292440 & 0.0000 \\
\hline GRO & 0.613980 & 0.185642 & 3.307339 & 0.0010 \\
\hline \multicolumn{5}{|l|}{ Weighted Statistics } \\
\hline R-squared & 0.180864 & \multicolumn{2}{|c|}{ Mean dependent var } & 0.956283 \\
\hline F-statistic & 15.63992 & \multicolumn{2}{|c|}{ Durbin-Watson stat } & 0.702267 \\
\hline Prob (F-statistic) & 0.000000 & & & \\
\hline
\end{tabular}


Table 4: Hausman test results

\begin{tabular}{|c|c|c|c|c|}
\hline \multicolumn{5}{|c|}{ Correlated Random Effects - Hausman Test } \\
\hline \multicolumn{5}{|l|}{ Equation: Untitled } \\
\hline \multicolumn{5}{|c|}{ Testcross-section random effects } \\
\hline Test Summary & & Chi-Sq. Statistic & Chi-Sq. d.f. & Prob. \\
\hline Cross-section random & & 20.007907 & 6 & 0.0028 \\
\hline \multicolumn{5}{|c|}{ Cross-section random effects test comparisons: } \\
\hline Variable & Fixed & Random & Var(Diff.) & Prob. \\
\hline BEP & -3.656765 & -3.773903 & 0.053142 & 0.6114 \\
\hline SOL & -0.014037 & -0.021734 & 0.000019 & 0.0767 \\
\hline SIZE & 2.385912 & 1.841676 & 0.237634 & 0.2642 \\
\hline INT & 0.587310 & 0.928533 & 0.059490 & 0.1618 \\
\hline LAR & -0.714408 & -2.157300 & 0.113288 & 0.0000 \\
\hline GRO & 0.492173 & 0.613980 & 0.006323 & 0.1256 \\
\hline
\end{tabular}

Table 5: Test results of removing 3 variables INT, SOL, LAR from the model

\begin{tabular}{|c|c|c|c|c|}
\hline \multicolumn{5}{|c|}{ Redundant Variables: INT SOL LAR } \\
\hline F-statistic & 0.696550 & \multicolumn{2}{|c|}{ Prob. F(3,372) } & 0.5546 \\
\hline Log likelihood ratio & 2.419900 & \multicolumn{2}{|c|}{ Prob. Chi-Square(3) } & 0.4899 \\
\hline \multicolumn{5}{|l|}{ Test Equation: } \\
\hline \multicolumn{5}{|c|}{ Dependent Variable: CS } \\
\hline \multicolumn{5}{|c|}{ Method: Panel Least Squares } \\
\hline \multicolumn{5}{|c|}{ Date: 08/12/20 Time: 10:39 } \\
\hline \multicolumn{5}{|l|}{ Sample: 20122019} \\
\hline \multicolumn{5}{|l|}{ Periods included: 8} \\
\hline \multicolumn{5}{|c|}{ Cross-sections included: 54} \\
\hline \multicolumn{5}{|c|}{ Total panel (balanced) observations: 432} \\
\hline Variable & Coefficient & Std. Error & t-Statistic & Prob. \\
\hline C & -17.13579 & 4.564593 & -3.754068 & 0.0002 \\
\hline BEP & -3.758461 & 0.925867 & -4.059397 & 0.0001 \\
\hline SIZE & 2.317319 & 0.532864 & 4.348798 & 0.0000 \\
\hline GRO & 0.485227 & 0.196978 & 2.463352 & 0.0142 \\
\hline \multicolumn{5}{|l|}{ Effects Specification } \\
\hline \multicolumn{5}{|c|}{ Cross-section fixed (dummy variables) } \\
\hline R-squared & 0.709575 & \multicolumn{2}{|c|}{ Mean dependent var } & 2.629145 \\
\hline F-statistic & 16.36093 & \multicolumn{2}{|c|}{ Durbin-Watson stat } & 0.727937 \\
\hline Prob (F-statistic) & 0.000000 & & & \\
\hline
\end{tabular}


- Test to remove variables from the model:

The purpose of removing variables from the model is to exclude variables that have no impact on dependent variables. Using the method of elimination and testing, remove each variable from the model and use E-view software to verify. After running the software, we see that at most 3 variables can be removed: INT, SOL, LAR.

To conduct the test to remove 3 variables INT, SOL, LAR from the initial regression model, we test the following hypothesis pair:

Testing hypotheses:

$\left\{\begin{array}{l}H_{0}: \beta_{3}=\beta_{5}=\beta_{6} \\ H_{1:} \beta_{j} \neq 0(j=3,5,6)\end{array}\right.$

Prob. $\mathrm{F}=0.5546>0.05$. Not enough to reject $\mathrm{H}_{0}$.

So, it is possible to remove 3 variables INT, SOL, LAR from the model.

Prob(F-statistic $)<0.05$. The regression function is appropriate.

The model of factors affecting capital structure is:

$$
C S_{i}=\alpha_{1}+\alpha_{2} B E P_{i}+\alpha_{3} S I Z E_{i}+\alpha_{4} G R O_{i}
$$

Sample regression function:

$$
\begin{aligned}
C S_{i}= & -17.13579-3.758461 B E P_{i}+2.317319 \text { SIZE }_{i} \\
& +0.485227 G R O_{i}
\end{aligned}
$$

\section{Discussion and Recommendations}

\subsection{Discussion}

In Table 5, $\mathrm{R}^{2}=0.709575$ states that in the regression model, three variables BEP, SIZE, GRO have a great influence on CS (Capital Structure), capable of explaining $70.9575 \%$ for CS fluctuations, meaning that $70.9575 \%$ change in ROA of construction companies listed on Hanoi Stock Exchange is caused by the impact of three variables BEP, SIZE, GRO.

$+\alpha_{2}=-3.758461$ means that profitability has an opposite effect on capital structure, while other factors are constant and if profitability increases by $1 \%$, capital structure decreases by $3,758461 \%$ and vice versa, showing that firms with high interest rates before interest rates and taxes often maintain debt ratios at a lower level. This can be explained by the fact that businesses with high business efficiency are often able to raise capital with internally-generated capital from retained earnings, thus less dependent on debt financing. Therefore, only when the capital demand exceeds the supply capacity from the content capital, the enterprise can mobilize from the loan. This is also consistent with the study of Baral (2004), Akhtar (2005), Gurcharan (2010),
Shubiri (2010), Akinlo (2011), Sharif et al. (2012), Nguyen and Nguyen (2020).

$+\alpha_{3}=2.317319$ means that the size of enterprises has the same impact on capital structure, meaning that large-scale construction enterprises are able to use debt at a higher level, when other factors remain unchanged and if the logarithm of the asset value increased by $1 \%$, the debt to equity ratio increased by $2,317319 \%$ and vice versa. This is explained by the fact that large-scale enterprises are more likely to have access to credit, so they have a higher debt ratio. This result is completely consistent with the study of Baral (2004), Akhtar (2005), Eriotis (2007), Liu et al. (2009), Gurcharan (2010).

$+\alpha_{4}=0.485227$ means that the growth rate of construction enterprises has a positive impact on capital structure, when other factors are constant and if the growth rate of enterprises increases by $1 \%$, the debt to equity ratio owning increased $0.485227 \%$ and vice versa. This shows that the growth of businesses is a supporting factor for accessing external capital through debt. This is the result supported by the studies of Baral (2004), Shubiri (2010).

Solvency (SOL) variables, average loan interest rate (INT), long-term asset ratio (LAR) do not affect capital structure. Although this is not similar to some previous studies, it is consistent with the characteristics of the construction businesses in the research sample.

\subsection{Recommendations}

From the mentioned discussion, it is possible to make some recommendations to help construction enterprises improve the capital structure as follows:

- On the basis of the estimation model, enterprises with large capital scale and growth opportunities should take advantage of the ability to access credit capital from banks, thereby making good use of financial leverage to improve operational efficiency of the business. In addition, enterprises with high business efficiency need to bring into play endogenous capital well to reduce debt mobilization coefficient in order to restructure capital sources of enterprises.

- Construction enterprises need to increase profitability. The statistics show that the average interest rate (INT) is approximately the profitability before interest and tax of the business (BEP) and the lower the BEP, the more the debt. If an enterprise has the possibility that the average loan interest rate is greater than the profitability before interest and tax, then the enterprise will not take advantage of financial leverage, therefore, using more debt financing not only increases the financial risks but also reduces the profitability of equity.

- Enterprises need to focus on financial risk management, especially when the debt to equity ratio of construction enterprises is very high currently, the management of financial risk is essential. If the enterprise fails to achieve 
the expected profits, the interest expense and principal will become a burden for the enterprise

- Improving solvency. To prevent insolvency due to excessive debt on equity, businesses need to regularly analyze their financial situation to identify insolvency risks, plan detailed cash flow. In the short term, it is possible to increase the ability to generate cash to ensure solvency.

- The results from the analysis of the model also indicate that construction enterprises need to recognize the importance of building target capital structures. Enterprises need to base on their plans and development orientations as well as their ability to raise capital to build target capital structures. In addition, businesses also need to regularly monitor the capital structure of the business and promptly adjust the capital structure when there are unusual changes in the macroeconomic situation and the development strategy of the business.

\section{Conclusion}

In summary, through a set of data collected from 54 construction companies listed on Hanoi Stock Exchange from 2012 to 2019, the article studies the factors affecting the capital structure of construction companies listed on Hanoi Stock Exchange. The empirical model has shown the correlation between intrinsic factors to capital structure including: the increase in growth factor, firm size have a positive correlation to the capital structure, the opposite effect of profitability factor on capital structure, and such factors as solvency of short-term debt, average loan interest rate and tangible asset structure have no correlation with capital structure. These results have provided useful information for construction companies in managing the capital structure of their enterprises. The model of factors affecting the capital structure of construction companies listed on the Hanoi Stock Exchange in the period 2012-2019 is a suggestion for these businesses in the capital structure planning process as well as forecast capital structure when there are changes of factors. The study of the factors affecting the capital structure of companies is relatively important for managers, planning the capital structure of enterprises, therefore financial managers need to pay special attention to the knowledge involved in making decisions on capital structure.

\section{References}

Abor, J. (2005). The effect of capital structure on profitability: An empirical analysis of listed firms in Ghana. The Journal of Risk Finance, 6(5), 438-445.

Addae, A.A., Baasi, M. N., \& Hughes, D. (2013). The effects of capital structure on profitability of listed firms in Ghana. European Journal of Business and Management, 5(31), 215-229.
Akhtar, S. (2005). The determinants of capital structure for Australian Multinational and Domestic Corporations. Australian Journal of Management, 30(2), 321- 341.

Akinlo, O.(2011). Determinants of capital structure: Evidence from Nigerian panel data. African Economic and Business Review, 9(1), 1-16.

Baker, M., \& Wurgler, J. (2002). Market Timing and Capital Structure. The Journal of Finance, 57(1), 1-32.

Baral, K. J. (2004). Determinants of capital structure: A case study of listed companies of Nepal. The Journal of Nepalese Business Studies, 1(1), 1-13.

Barclay, M. J., Smith, C. W., \& Watts, R. L. (1995). The determinants of corporate leverage and dividend policies. Journal of Applied Corporate Finance, 7(4), 4-19.

Brealey, R. A., Myers, S. C., \& Marcus, A. J. (2009). Fundamentals of corporate finance ( $6^{\text {th }}$ ed.). New York, NY: McGrawHill/ Irwin.

DeAngelo, H., \& Masulis, R. W. (1980). Optimal capital structure under corporate and personal taxation. Journal of Financial Economics, 8(1), 3-29. https://doi.org/10.1016/0304-405x(80) 90019-7

Eriotis, N. (2007). How firm characteristics affect capital structure: An empirical study. Managerial Finance, 33(5), 321-331.

Fischer, E. O., Heinkel, R., \& Zechner, J. (1989). Dynamic Capital Structure Choice: Theory and Test. The Journal of Finance, 19-40.

Gentry, W. M. (1994). Taxes, Financial Decisions and Organizational Form: Evidence from Publicly Traded Partnerships. Journal of Public Economics, 53, 223-244.

Gropp, R. (1995). Corporate Taxation and Capital Structure choice in Germany. Finanz Archiv, 52, 196-211.

Gurcharan, S. (2010). A review of optimal capital structure determinant of selected ASEAN countries. International Research Journal of Finance and Economics, 47, 30-41.

Harris, F. H. (1988). Capital Intensity and the Firm's Cost of Capital. Review of Economics and Statistics, 52(4), 587-595.

Huynh, B. T. (2020). Factors affecting the capital structure of food and beverage businesses listed on the Ho Chi Minh City stock exchange. Industry and Trade Magazine. Retrieved July $30^{\text {th }}$, 2020, from: http://www.tapchicongthuong.vn/bai-viet/mot-sonhan-to-tac-dong-den-cau-truc-von-doanh-nghiep-nganh-thuc -pham-va-do-uong-niem-yet-tren-so-giao-dich-chung-khoanthanh-pho-ho-chi-minh-hsx-70693.htm

Khan, K., Qu, J., Shah, M. H., Bah, K., \& Khan, I. U. (2020). Do Firm Characteristics Determine Capital Structure of Pakistan Listed Firms? A Quantile Regression Approach. Journal of Asian Finance, Economics and Business, 7(5), 61-72. https:// doi.org/10.13106/jafeb.2020.vol7.no5.061

Liu, Y., Ren, J., \& Zhuang, Y. (2009). An empirical analysis on the capital structure of Chinese listed IT companies. International Journal of Business and Management, 4(8), 46-51. 
Michaely, R., Thaler, R. H., \& Womack, K. L. (1995). Price reactions to dividend initiations and omissions: Overreaction or drift? Journal of Finance, 50, 573-608.

Modigliani, F., \& Miller, M. (1958). The cost of capital, corporate finance, and the theory of investment. The American Economic Review, 48(3), 291-297.

Mohammad, H. S., Bujang, I., \& Hakim, T. A. (2019). Capital structure and financial performance of Malaysian construction firms. Asian Economic and Financial Review, 9(12),1306-1319.

Morri, G., \& Cristanziani, F. (2009). What determines the capital structure of real estate companies? An analysis of the EPRA/NAREIT Europe Index. Journal of Property Investment \& Finance, 27(4), 318-372. https://doi. org/10.1108/14635780910972288

Mukhibad, H., Subowo, S., Maharin, D. O., \& Mukhtar, S. (2020). Determinants of Debt Policy for Public Companies in Indonesia. The Journal of Asian Finance, Economics and Business, 7(6), 29-37. https://doi.org/10.13106/jafeb.2020.vol7.no6.029

Nirajini, A., \& Priya, K. (2013). Impact of capital structure on financial performance of the listed trading companies in Sri Lanka. International Journal of Scientific and Research Publications, 3(5), 1-9.

Nguyen, H. T., \& Nguyen, A. H. (2020). The Impact of Capital Structure on Firm Performance: Evidence from Vietnam. Journal of Asian Finance, Economics and Business, 7(4), 97-105. https://doi.org/10.13106/jafeb.2020.vol7.no4.97
Rajan, R. G., \& Zingales, L. (1995). What do we know about capital structure? Some evidence 6 from international data. Journal of Finance, 50, 1421-1460.

Ross, S.A(1977). The determination of financial structure: the incentive signalling approach. Bell Journal of Economics, 8, 23-40.

Ross, S. A., Westerfield, R. W., \& Jordan, B. D. (2001). Essentials of corporate finance (3rd ed.). New York, NY: McGraw-Hill.

Shah, A. and Khan, S. (2007). Determinants of capital structure: Evidence from Pakistani panel data. International Review of Business Research Papers, 3(4), 265-282.

Sharif, B., Naeem, M. A., \& Khan, A. J. (2012). Firm's characteristics and capital structure: A panel data analysis of Pakistan's insurance sector. African Journal of Business Management, 6(14), 4939-4947.

Shubiri, F. A. (2010). Determinants of Capital structure choice: A case study of Jordanian Industrial Companies. An-Najah Univ. J. of Res. (Humanities), 24(8), 2457-2494.

Teker, D., Tasseven, O., \& Tukel, A. (2009). Determinants of capital structure of Turkish firms: A panel data analysis. International Research Journal of Finance and Economics, 29, 179-187.

Titman, S., \& Wessels, R. (1988). The determinants of capital structure choice. Journal of Finance, 41, 1-19.

Wald, J. K. (1999). How firm characteristics affect capital structure: An international comparison. Journal of Finance Research, 22, 161-187. 